Article

\title{
Tourism Pedagogy and Visitor Responsibilities in Destinations of Local-Global Significance: Climate Change and Social-Political Action
}

\author{
Tazim Jamal ${ }^{1, *}$ and Brian Smith ${ }^{2}$ \\ 1 Department of Recreation, Park and Tourism Sciences, Texas A\&M University, 600 John Kimbrough Blvd. \\ 409M AGLS, 2261 TAMU, College Station, TX 77843-2261, USA \\ 2 Independent author, \#302, 2211 29th St. SW, Calgary, AB T3E 2K1, Canada; dcg_brian@hotmail.com \\ * Correspondence: tjamal@tamu.edu; Tel.: +1-979-845-6454
}

Received: 30 April 2017; Accepted: 14 June 2017; Published: 21 June 2017

\begin{abstract}
This paper examines the issue of climate change pedagogy and social action in tourism, with particular interest in globally-significant destinations under threat from climate change. Little is understood of the role and responsibility of visitors as key stakeholders in climate change-related action or the potential of such sites to foster environmental learning, as well as social and political action on climate change. Drawing on insights from Aldo Leopold and John Dewey, it is argued here that destinations that are valued intrinsically for their ecological and cultural importance are (or ought to be) sites of enjoyment and pedagogy, facilitating experiential learning, care, responsibility and civic action towards their conservation. An exploratory case study of visitors to the Great Barrier Reef offers corroborative insights for such a "reef ethic" as described in this paper, related to visitor experience, learning and action in this World Heritage Area. The results of this paper support the need for a stronger pedagogic role to be adopted by tourism experience providers and site managers to facilitate climate change literacy and responsible action (hence facilitating global environmental citizenship). Their responsibility and that of reef visitors is discussed further.
\end{abstract}

Keywords: climate change; tourism pedagogy; visitor responsibility; political action; Great Barrier Reef World Heritage Area

\section{Pressures and Challenges to Global Marine Resources}

Coastal and marine resources such as coral reefs worldwide are increasingly under threat from climate change as well as other challenges, such as detrimental fishing practices (e.g., overfishing), coastal development, land and marine-based pollution (see below). The costs range from environmental to social and economic. Consider the Great Barrier Reef, protected by UNESCO as a World Heritage Area, containing the world's largest collection of coral reefs, with 400 types of corals, 1500 species of fish, and it is the habitat for species such as the dugong ("sea cow") and the large green turtle, which are threatened with extinction (see [1,2]). Currently, almost $70 \%$ of the Great Barrier Reef (GBR) has undergone coral bleaching (directly related to global warming), with back-to-back bleaching events in 2016 and 2017 devastating $1500 \mathrm{~km}$ (900 miles) of this iconic World Heritage [1]. The reef generates around $\$ 3.7$ billion annually for Australia; about 275 million people globally directly rely on reefs for livelihood and sustenance, and coral reefs globally form the nurseries for around a quarter of the world's fish [1]. The IUCN World Heritage Outlook 2014 finds the World Heritage values of the GBR are of "high concern" [2]. The Australian government has recently initiated the Reef 2050 Long-Term Sustainability Plan [3] to ensure the reef continues to be of outstanding universal value for current and future generations. The report acknowledges early that "Aboriginal and Torres Strait Islander peoples are the Traditional Owners of the Great Barrier Reef area and have a continuing connection to their 
land and sea country" [3], as also noted on p. 40 in Section 4.7 Heritage: "The sea, its natural resources and our identity as Traditional Owners, are inseparable ... Our ancestors have hunted and fished in this sea country since time immemorial ... " (Girringun Aboriginal Corporation). Climate change threatens hunting and fishing, as well as traditional and cultural practices; some sacred sites are at risk for the greater than 70 traditional owner groups who call it home [4]. Losses continue similarly elsewhere. A 30\% loss of corals off the coast of Kenya (Mombasa) and Tanzania (Zanzibar) created tourism-related economic losses of about US\$12-18 million (Payet and Obura [5], cited in Hall [6]). The study of coralline beaches and ecotourism in the Dominique Republic indicates that current rates of beach erosion could result in significant revenue losses to the hotel industry, but if corals continue to die off, beach erosion (and hence, tourism revenue loss) would be substantially higher; the report's recommendations include: "Increase public awareness about marine and coastal ecosystems, the benefits they provide to society, and threats to their existence" (Wielgus et al. [7] (p. vii)).

One of the questions this raises is the role of tourism and tourists, both in awareness raising and responsibility to address global environmental issues, presuming action ought to follow such awareness raising. Tourists, after all, are temporary visitors elsewhere, but are "residents" with civic responsibilities when they return home. As the literature review below indicates, little is understood of how they view their roles and responsibilities towards destinations such as the Great Barrier Reef, which is ecologically valuable and a global cultural heritage. The GBR was the first World Heritage property for which a comprehensive Tourism and Climate Change Action Strategy was developed (Great Barrier Reef Marine Park Authority (GBRMPA) [8]; see also [4]). The strategy recognizes the vital importance that a healthy GBR ecosystem plays for the Australian economy and that the tourism industry must quickly come to grips with the problem. Recommended actions include reducing direct impacts and greenhouse gas emissions from tourism companies operating on or near the reef; increased training and awareness for guides and operators; helping to raise public understanding of the threat and; supporting scientific research and monitoring activities [8]. In the more recent Reef 2050 report [3], under Section 5.7 Partners, on p. 62, under principle partners and their role, the tourism is referred to as follows:

Reef-dependent industries, including tourism and fishing, rely on a healthy environment for their economic sustainability. These industries implement practices to minimize environmental harm, adapt industry and community to the effects of climate change, and promote understanding and appreciation of the Reef's values.

Yet, while the call for public communication and public awareness has been a repeated one with steady efforts made by GBRMPA and local educational organizations (see [9]), the role and potential of tourism and the responsibility of key tourism stakeholders remain under-studied. The condition of the reef and its immensely valuable ecological and cultural significance raise both ethical and practical questions that can no longer be ignored by tourism researchers and practitioners. These become even more complicated when considering the scale and scope of the tourism system, which extends from the local to the global. Destinations like the Great Barrier Reef (GBR) are especially problematic from a sustainability perspective as they (i) represent globally significant cultural heritage under severe threat from multiple sources including climate change [10]; and (ii) are complex governance domains: they present significant management challenges as they are protected areas of social-cultural significance from the local to the global level and often entail cross-sectoral governance. They also contain multiple stakeholders whose diverse characteristics, values and interests may result in a wide range of perceptions and attitudes towards climate change and impact management (see [11,12]). The GBR, for instance, is a World Heritage Area and visitor destination, as well as a protected marine park, and its extensive geographic range off the east coast of Australia intersects multiple state and local jurisdictions and impacts numerous coastal communities. Increasing conflict is anticipated among local communities and tourism stakeholders whose livelihoods and well-being stand to be most affected by climate change (see $[1,2,13])$. Increasingly difficult economic and social tradeoffs will be required 
in the race to conserve such ecologically vital areas that are also culturally recognized as treasures to civilization to be sustained for current and future generations of residents and visitors.

Tourism-related policy making and leadership in natural area destinations of global heritage significance has been surprisingly slow to respond, despite increasing concern about tourism's contribution to climate change and the added stress of human activity related to the provision of tourism-related experiences and facilities (see [14]). Progress is being made on identifying and involving stakeholders and local communities in climate change impact management, but one key stakeholder continues to remain elusive in the complex management and governance of global heritage under danger: the tourist. While studies have explored tourist demand and behavior broadly in relation to climate change and adaptation to weather disruptions $[15,16]$, our understanding of how visitors relate to climate change in natural area destinations is highly limited [17]. Scott, Jones and Konopek [18] explored climate change scenarios with a wide range of visitors in the World Heritage Site of Waterton National Park, Canada. On the Great Barrier Reef, Turton, Hadwen and Wilson [19] used an extensive multi-stakeholder process to examine the climate-resource relationship and tourism, but their study did not include tourists. Ramis and Prideaux [20] found that tourists were sensitive to changes in the condition of the reef and that climate change may have a major impact on visitation patterns in the future. However, the investigation of visitor knowledge, learning and role in climate action continues to lag, despite the increasingly threatened state of the Great Barrier Reef and the call for improved governance [21]. Very little is known of their role or potential importance in social action, particularly in the context of global citizenship and civic action in world heritage destinations under threat from climate change (see, for instance, [22]). This is the research problem that this article undertakes to investigate.

A key question that arises here is whether tourists should be treated not merely as a stakeholder, but as a key stakeholder in issues of climate change in protected areas like the Great Barrier Reef. What responsibility do they have towards protected areas that constitute global heritage in terms of preservation for future generations of citizens and tourists? What responsibility ought they to have toward places of special significance to civilization? Should tourists be asked to undertake civic duties such as calling for policy action to manage threats to reef health and duties of sustainable stewardship that may include managing the impacts of their own carbon emission and the water and energy they consume during their holiday? If so, is there not a responsibility towards pedagogic action on the part of reef stakeholders such as tourism experience providers (e.g., awareness raising, facilitating greater environmental literacy among the traveling public)? Such questions of global environmental citizenship and civic action require close attention to the role of tourism, tourists, tourism experience providers and destination managers in this challenging 21st century landscape where climate change is one of the biggest threats facing populations and countries globally. While much has been said and studied about tourism "impacts" and approaches like "sustainable tourism", "responsible tourism", and "ecotourism", it is puzzling to see how little progress has been made to address crucial questions such as the above. Now is not too late to investigate more carefully the role and potential of tourism in the face of global environmental and related socioeconomic challenges, which we argue below is underutilized in terms of pedagogy and civic action.

The purpose of this paper is therefore two-fold: (1) to explore the pedagogical tension that plays out in the tourism destinations about whether to "bother" visitors with challenging information like climate change or other environmental threats to natural area destinations like the GBR (a World Heritage Area), and forward a "reef ethic" for pedagogy, play and responsible action; (2) to discuss results from an exploratory study of reef visitors in light of the first objective. The exploratory Great Barrier Reef visitor survey reported below was gathered a couple of years ago (2013-2014); it offers a small, but insightful case study to inform this discussion. The following research questions guided the study's focus on understanding visitors' experiences, perceptions and opinions in relation to climate change (among other environmental threats), learning and social action in this iconic world heritage destination: 
- What do visitors experience at the reef (what is most/least memorable)? What would they like to learn more about?

- Do visitors learn about climate change impacts and other environmental issues during their visit to the GBR? If yes, where and how do they receive this information?

- How informed do visitors feel about environmental challenges facing the GBR (including climate change)? Would they like additional information? If yes, at what stage (pre-trip, on-trip, post-trip)?

- What are visitors' perceptions with respect to political action and stakeholder responsibilities to address environmental threats to the GBR? What level of responsibility are tourists themselves willing to undertake?

This small case study reinforces the main thesis of this article in terms of the important pedagogic role and responsibility of tourism and its stakeholders in such global heritage sites to: (i) facilitate an informed visiting public with respect to climate change literacy; and (ii) facilitate climate action through such an informed public that engages in responsibility and action (consider this, then, global environment citizenship acting here in the context of World Heritage Sites). The ethical imperative that supports such praxis (practical action and change) is explored below, followed by the case study and a subsequent discussion section.

\section{Play and Pedagogy: Synergistic Partners or Tense Opponents in Tourism?}

\subsection{Information Deficit and Visitor (In)Action}

After an extensive review of social and environmental impacts, responses and indicators for the tourism sector, Buckley [23] (p. 528) identified "the effects of individual perceptions of responsibility in addressing climate change" as a crucial future agenda. The research literature indicates that leisure visitors range widely from aware and conscientious to less aware/uninterested with respect to their relationship to climate change in travel. Dawson et al.'s [24] study of long-haul tourists and their perceptions of climate change consisted of 334 on-site visitor surveys plus 18 individual interviews around Churchill, Canada, a popular site for polar tourism. Their results showed that many visitors did not recognize the link between their own long-haul air travel to the Arctic and climate change. However, almost half (48\%) expressed intent to reduce their GHG emissions after they returned home, and seven percent had purchased carbon offsets for their air travel to Churchill. Higham and Cohen's [25] study of Norwegian travelers concerned about their contribution to climate change showed that these tourists continued to engage in "air travel with a carbon conscience". Their study comports with Gössling, Haglund, Kallgren, Revahl and Hultman's [26] research, but it should be noted that research is generally lacking on such visitors in terms of subsequent action undertaken for managing their climate change impacts.

In contrast to the above, a study of U.K. travelers by Hares et al. [27] showed climate denial coupled with reluctance to change travel behavior. Other studies of international tourists indicate awareness of global warming and climate change, but also show reluctance to act, e.g., to alter travel behaviors or contribute to carbon offset schemes [28-30]. Becken [31] found that tourists distinguished between their travel and their everyday life; responsibility for mitigation was perceived to be greater in the home world than in their travels. Most of these studies indicate an information deficit (as mentioned by Hares et al. [27]), which seems to support the need for greater awareness raising and information dissemination among the traveling public (see also Dickinson, Robbins and Lumsdon [32]). Pidgeon's [33] comprehensive report shows an urgent need for public environmental literacy and an active, informed citizenry to engage in adaptive planning and facilitate policy changes related to the increasing threats of climate change on places like the Great Barrier Reef. Therefore, why do leisure travelers appear to be generally ill-informed about environmental impacts (unless traveling on an "ecotourism" certified trip perhaps) and the actions that they might undertake to help address these? 
"Public interest" in Western tourist-generating countries is typically determined in terms of economics and markets, as Bartle [34] put it. Market capitalism and related globalization interests, oriented towards growth based on increased consumption of goods and services, foster sociocultural perceptions (myths?) of leisure travel whereby leisure travelers have a sacrosanct right to fun and enjoyment of their holiday spaces hedonistically and aesthetically only, offering interpretive understanding of environmental issues, and threats risk reducing fun and may even keep visitors away through negative media. Why worry the visitor about issues of climate change, resource depletion and environmental degradation, when they come for leisure and relaxation paid for by hard-earned savings (see [35])? Surely, everyone has the right and freedom to travel for touristic pursuits and not to be informed or made aware of the environmental costs and social consequences by which the associated leisure benefits are procured; this would be the claim if one followed the modernist paradigm rooted in market capitalism and its associated paradigm of transnational neoliberalism aided by the advent of globalization.

At the moment when climate change is one of the biggest threats facing human populations and environmental sustainability in the 21st century, surely the response is "no" and that there is a responsibility for the traveling public, destination managers and service providers to be informed about and care for both the ecological and cultural places we value. Additionally, what if such ecological places are also places of immense value to civilization as represented by the UNESCO designation of "World Heritage"? The Great Barrier Reef, for instance, is under immense environmental pressure as described in the next section, and it is valued globally (it is a World Heritage Site, after all) and by domestic Australians for its cultural and ecological significance. Goldberg et al. [36] (p. 1) conducted a recent survey of domestic Australians and concluded that "climate change is perceived to be the biggest threat to the Great Barrier Reef, and that the Great Barrier Reef inspires Australians, promotes pride, and instills a sense of individual identity and collective responsibility to protect it". Should such sites and the experiences they offer to domestic and international visitors merely be destinations to "play" in, or should they also be places of pedagogy, contributing to environmental literacy, fostering global environmental citizenship and climate action to conserve them for current and future generations of residents and visitors?

\subsection{Aesthetic Experience and Learning: Towards a Reef Ethic}

Aldo Leopold would unhesitatingly say yes, and his land ethic offers valuable principles that even ecofeminists who criticize various aspects of it agree with and advocate as necessary for a genuine environmental ethic. Warren [37], for instance, draws on the importance he placed on personal direct experience and perception interwoven with thoughtful receptivity, a relationship not reducible to scientific facts or instrumental economic value. Building receptivity involved building affective, caring connections with nature and natural things. Such a relationship should be one of direct engagement and also an enjoyable one:

The human relation to land...is, or should be, aesthetic as well [as economic]... If the individual has a warm personal understanding of land, he will perceive of his own accord that it is something more than a bread-basket. He will see land as a community of which he is only a member, albeit now the dominant one. He will see the beauty, as well as the utility, of the whole, and know the two cannot be separated. We love (and make intelligent use of) what we have learned to understand... Once you learn to read the land, I have no fear of what you will do to it, or with it. And I know many pleasant things it will do to you [38] (p. 337), cited in [39] (p. 495).

Pleasure, play, recreation and enjoyment are therefore vital components of a good environmental ethic and are not incompatible with care and conservation. Numerous rich, evocative stories in $A$ Sand County Almanac [40] illustrate the possibility to cultivate receptivity through enjoyable encounters. As Norlock [39] (p. 498) explains, "the pleasures to be had in nature, in recreational fun and aesthetic 
appreciation are good partly because they incline one to be receptive, to cultivate attentiveness and practices of caring". Cultivating an ecological conscience comes from within, from a heartfelt, personal engagement with the natural world, and not from external scientific facts (though the latter is indispensable in Leopold's land ethic). It is this affective, aesthetic relationship that gives purpose and meaning to abstract scientific knowledge and helps to cultivate "intellectual humility", a term described in his essay "Defenders of Wilderness" ([40] (p. 279), cited in [39] (p. 507)). What is at stake here is an ethical relationship with scientific and economic interests, which should serve the end of developing a deep human sensibility and responsibility for the biophysical world. As Light [41] (p. 183) put it, the broader political spirit of $A$ Sand County Almanac leads us to a modest environmentalism that is "built upon the invocation of shared democratic experience and traditions". Leopold's project of conservation education was as much political as it was ethical; he saw it as involving civic education and civic persuasion towards democratic citizenship in the land. Wilderness as a source of democratic recreation was a "cultural inheritance", and conservation education was needed toward its preservation, but it was enacted through direct participation and self-expression in the landscape, not through economic (or scientific) dogma [42] (p. 178).

Scientific (conservation) education and direct, affective experience were inseparable for Leopold, and his democratic pedagogy resonates with John Dewey's [43] emphasis on progressive democratic education for dealing with social, ethical and political problems; it involved enabling active involvement in community development, community organization and democratic participation through hands-on involvement and experiential learning. For Dewey, experience is a matter of perception where existing meanings and new meanings are rearranged in consciousness, as mind encounters the world. In his early work Democracy and Education that was first published in 1915, Dewey [43] (p. 89), argues for socially-rich associations between groups and individuals through experiential encounters that facilitate practical wisdom. Aesthetic encounters, however, perform an addition function, for the "ability to produce and to enjoy art, capacity for recreation, the significant utilization of leisure", for they provide the means to communicate the affective and intellectual side of experience [43] (p. 89). Elaborating on this further in Art as Experience (first published in 1934), he argues that aesthetic expression demonstrates that "there are no intrinsic psychological divisions between the intellectual and the sensory aspects; the emotional and ideational; the imaginative and the practical phases of human nature" [44] (p. 258). As Raber [45] (p. 340) points out, experiential education and science perform an important democratic function, then:

Science should be taught by beginning with concretely experienced relations and working outward to more distant connections ... Since our relation to the things in the world is always, at best, one of interest, in which our minds are modified by the interaction, this notion of science ... can be seen as a buttress for the quality of freedom. "Since democracy stands in principle for free interchange, for social continuity", Dewey reasons, "it must develop a theory of knowledge which sees in knowledge the method by which one experience is made available in giving direction and meaning to another" [43] (p. 248); cited in [45] (p. 340).

John Dewey's democratic pedagogy is grounded in experiential education and covers a very large corpus of work that is beyond the scope of this article. The purpose of this brief foray into his work is to note the remarkable synergies it has with Aldo Leopold's land ethic, with respect to a pedagogy that embraces democracy and social action (e.g., conservation action for Leopold, social activism for Dewey), experiential education, the importance of aesthetic encounters and the indivisibility of affective and intellectual aspects of human experience (see [46], as well). These offer a powerful pedagogy for tourism destinations such as the GBR that constitute complex ecological social and political systems, in which local and global sustainability issues are being negotiated and addressed. Following Leopold and Dewey above, it can be argued that they are sites of pleasure and pedagogy, where aesthetic and scientific aspects are complement partners in experiential education encounters. Informed visitors with rich, engaging and enjoyable ("memorable"?) experiences develop 
care for the reef and feel a sense of social responsibility to act for its conservation for others to enjoy it. Summarizing the above reasoning:

(i) I value the reef intrinsically, and that it is a World Heritage Site means other people value the Great Barrier Reef intrinsically, as well.

(ii) Insofar as people intrinsically value the reef, they ought to care about its conservation for current and future generations to enjoy and learn from.

(iii) To care for the Reef properly means I/people need information (e.g., scientific knowledge about the condition of the reef, minimizing own/other impacts, engaging others to help care for the reef).

(iv) Tourism and recreation at the reef provide opportunities for experiential education about the reef (following Leopold and Dewey, they are joint aesthetic and educational encounters, offering enjoyment and knowledge).

It would follow, then, that as a World Heritage Site under threat from climate change, the Reef is (or ought to be) a site of for fostering climate change literacy, global environmental citizenship and engaging self and others in social or political action. The ethical imperative to conserve the reef is grounded in relations of care and responsibility that arise from the perception of the intrinsic value of the reef through experiential education. Gaining knowledge of the threats facing the reef entails "intellectual humility" with respect to how to act in light of that information. Democratic responsibility has to be apportioned carefully here. Who is most responsible for the reef and what role can the visiting public (resident or international) play? They generally face competing moral responsibilities, e.g., towards caring for aging family members/their children or dealing with entrenched poverty and other social injustices, etc. Comporting with Leopold and Dewey, it would seem that the reef visitor's democratic responsibility is not insignificant. One line of reasoning here might be as follows:

(i) I see how beautiful the reef is;

(ii) I have knowledge of environmental threats and climate change impacts that are affecting the reef severely;

(iii) I therefore have responsibility to act towards conserving the reef.

One assumption here is that this line of reasoning extends toward individuals, but can be similarly adapted to organizations. It would seem here that two prima facie claims can be made about responsible parties here: (i) greater responsibility falls on those who have the power or ability to make a difference; and (ii) greater responsibility falls on those in closer proximity to the reef than further. In the context of the Great Barrier Reef, this means that the stakeholders most responsible for facilitating responsible conservation actions include, but are not limited to: (i) public sector authorities related directly to site governance (local/regional government closest to the site and related organizations such as the Great Barrier Reef Marine Park Authority (GBRMPA), as well as national government); (ii) nongovernmental or quasi-governmental organizations, e.g., UNESCO, an influential player in governance, but not a proximal stakeholder, plus local to regional NGOs; (iii) reef users including industries like fishing, coastal agriculture, shipping, reef tourism experience providers; (iv) other local tourism service providers and suppliers; (v) residents; (vi) local to national visitors and international visitors (whose long-haul carbon emissions contribute directly to climate change, unless offset in some way). It should be noted, as well, that in addition to conservation actions (conservation policy, planning, mitigation and adaptation, impact management, etc.), it can be argued that site managers like GBRMPA and experience providers like the reef tour operators have a responsibility to inform and educate the visiting public (using experiential education as per Leopold and Dewey where possible). If the public (residents, local recreationalists, domestic and international travelers) are not well informed, they will be unable to participate effectively in civic or social/political action.

The small exploratory reef survey below explores the research problem and argument laid out above and examines how visitors relate to the reef, their experiences and learning, knowledge and 
perceptions, as well as concern and caring for global heritage in danger. It offers some helpful insights into tourism's role in climate change pedagogy and responsible action at the GBR, corroborating the importance of a local-global approach and multi-stakeholder involvement (including the visiting public) to address reef conservation in the face of climate change and other environmental challenges.

\section{The Great Barrier Reef, Australia}

\subsection{Background and Setting}

The GBR covers approximately 348,000 square kilometers, most of which lies within the Great Barrier Reef Marine Park [3]. Located within this complex region, the boundaries of this study extend from Cairns south to Mission Beach and north to Cape Tribulation. The economic significance of tourism in this region is well documented [47], but less is known about the potential impacts of climate change. Impacts on vertebrate populations, birdlife, temperature, rainfall and weather, plus landscape changes caused by extreme weather events are expected to have a significant impact on tourism [48]. Increases in water temperature above $2{ }^{\circ} \mathrm{C}$ [49] are expected to have severe implications for the health of coral reefs, fisheries and coastal ecosystems. The Great Barrier Reef has undergone eight mass bleaching events since 1979 (1980, 1982, 1987, 1992, 1994, 1998, 2002 and 2006), with the most severe in 1998 and 2002 affecting about $42 \%$ and $54 \%$ of reefs, respectively ([50]; cited in [6]).

In addition, the cumulative effects of a range of environmental and human impacts need to be factored in. Local anthropogenic issues, such as pollution, over-fishing, agricultural runoff and other sources of sediment discharge, increase the vulnerability of reef ecosystems to climate change-related effects such as ocean acidification. Increasing impacts from incidents such as cyclones and Crown of Thorns starfish invasion (COTS, predatory star fish that eats coral polyps) attacks continue to raise concern about the threats facing this iconic destination ([10]; see also [51,52]). The Queensland State Government's approval of extensive dredging programs to open coal ports within the Great Barrier Reef Marine Park boundaries and continued ocean acidification and sea level rise contribute further uncertainty to the efforts of the Great Barrier Reef Marine Park Authority (GBRMPA) to manage individual and cumulative impacts on the reef (see [53,54]). Proactive management strategies implemented by the Great Barrier Reef Marine Park Authority and support by tour operators have greatly helped (e.g., through implementing green zones and strict regulatory oversight), but the governance challenge is exacerbated by the complex ecological-social system. Mitigation and adaptation in this iconic destination requires close cooperation and collaboration among stakeholders that include GBRMPA, UNESCO, the Australian commonwealth, state and local governments, nonprofit organizations (e.g., environmental NGOs), plus a host of other players mentioned earlier.

Sustainability principles are generally being followed by tour operators adhering to ecotourism certification, e.g., as related to boat operations (see, for instance, Chapter 5 in [54]) and trying to minimize direct visitor damage to coral and marine life, etc., through various communication strategies (e.g., [55]). Collectively, future climate change induced impacts are anticipated to adversely affect visitor experiences and enjoyment, such as diving at the reef [56]. Research on visitor knowledge and perceptions related to climate change and environmental impacts on the reef is limited, however, and the pedagogic role of the reef in relation to visitor responsibility and climate action remain greatly understudied. While some studies have commenced to examine Australian public perceptions of climate change and pro-environmental behavior (e.g., [57]), none have attempted to relate climate change literacy with civic responsibility and sustainability-oriented actions by the traveling public (i.e., tourists) to address environmental threats to the GBR. The exploratory study reported below offers a preliminary start in this filling this gap. Given the paucity of prior research on this topic, the survey was framed as a semi-structured, broad exploration of visitor experiences and learning, with particular reference to climate change and social action. Attempts to seek funding to conduct a larger study of reef visitors subsequent to this research were unsuccessful, delaying sharing the valuable insights provided by the survey participants. 


\subsection{The Exploratory Case Study}

To work around time and resource constraints, an exploratory Great Barrier Reef visitor survey was conducted online over time using SurveyMonkey. Small 3" $\times 5$ " index cards ("postcards") were developed containing an attractive picture of the reef on one side plus a brief description of the survey on the other as well as why it was important to complete the survey and the benefit to the visitor for doing so. Key marine industry stakeholders helped to distribute the index cards to a non-representative group of reef tour operators (six agreed to participate in the survey). The results contained within this report are thus not representative of the industry as a whole, but offer insights on a range of small to large operators.

Within the study region, most reef tour operators departing from Cairns and Port Douglas, the two key towns in the study area, have Australian ecotourism certification, and a few have advanced eco-certification. Reef tours range from day visits to reef islands and pontoons moored on the reef to overnight dive and whale watching trips. It took nearly an entire month to contact and meet with operators in order to get them to take part in the project. All respondents in our sample departed from Cairns.

Data collection commenced during the third week of July 2013. Color posters were also made to help sell people on participating in the project, supplementing approximately 9000 color postcards that were to be distributed. Each week, operators were to be contacted to see if they needed more postcards and to find out if there were any issues with distributing the postcards to passengers. A small number of postcards and posters were also delivered to some local area hotels/motels, shops and to a local educational organization called "Reef Teach" to distribute to people who might be interested in participating in the survey.

Usable responses were received from 25 July 2013 (North American time) to 7 June 2014. We considered a usable response to be any response in which the participant indicated which tour operator they used for their tour of the GBR. Since we did not have full control over the selection of participants, it is possible that more than one person from a party responded. An initial screening question was asked to determine if people had visited the GBR, and they were told upfront that they had to be at least 18 years of age to participate in the survey. The age constraint was put in place because it was felt that people under this age might not be able to fully comprehend all of the questions asked in the survey questionnaire. When the data collection process was completed, the data was downloaded into Microsoft Excel and then cleaned. The data was then analyzed using SPSS, Microsoft Excel and Microsoft Access. The final sample size for this exploratory visitor survey project was 98, enough to make some interesting observations from the data analysis, which provided a profile of GBR visitors that sailed out of Cairns, how they viewed GBR tours from that location, their experience and learning, perception and attitudes related to environmental and climate change impacts on the GBR, responsibility and action related to conservation and care of the reef for current and future generations.

In addition to the standard analysis of the data via frequencies, we also compared various subgroups of data to see if there were any statistically-significant differences. For example, this was done to see if there were differences based on age group, education level, gender, marital status and between Australian and international visitors to the GBR. We were especially interested to see if there were differences between Australian and international visitors when it came to their knowledge about impacts on the reef and their willingness to act to help alleviate those impacts. We tested to see if there were differences between the various groups using chi-square analysis and the nonparametric Mann-Whitney test. Unfortunately, there was either not enough data and/or too many subgroups to reach any conclusions that might be considered significant. Qualitative data in the form of open-ended respondent comments supplement the quantitative results and are discussed further below.

\subsection{Results}

The following section of the report provides an analysis of the results obtained from the survey and discusses them. The survey started off with a screening question to determine if the person had 
visited the GBR from either Cairns or Port Douglas. After determining which responses were usable for our purposes, this resulted in a sample size of 98 .

\subsubsection{Demographics}

Origin and Age of Respondents

After determining that the person had visited the GBR, the survey questionnaire began with a set of standard questions on demographics. Of the 92 people who provided information on country of origin, just over $60.9 \%$ were from Australia (with the majority being from Queensland, followed by New South Wales and Victoria), 20.7\% were from the United States, 7.6\% from the U.K. and the rest from elsewhere. The city/town with the most respondents (16.3\%) was Cairns, Australia. Just over $70 \%$ had been to other reefs either in Australia or elsewhere. Over two-thirds (68.8\%) of respondents who gave their age were between the ages of 25 and 54. The range of ages was from 20 to 82 with an average age of 38.0 and median of $35(n=93)$.

Education, Gender, Occupation and Household Income Level

Over half the respondents $(57.5 \%)$ had a bachelor's degree or higher $(n=94)$. Sixty-two-point-eight percent were female, and $37.2 \%$ were male. Respondents came from a wide range of occupations with office/clerical being the most mentioned occupation. Of 93 respondents, $43.0 \%$ had a household income level of $\$ 100,000$ or higher. A further $11.8 \%$ had a household income level of between $\$ 75,000$ and $\$ 99,999$, and $16.1 \%$ had between $\$ 50,000$ and $\$ 74,999$. Of the remainder, $9.7 \%$ declined to provide income information, and the remainder fell into various brackets below $\$ 50,000$.

\subsubsection{Reef-Related Visitation and Activities}

Of the 98 who responded, it was the first trip to the area for half $(49 \%)$, while $31(31.6 \%)$ were repeat visitors, and $17(17.3 \%)$ indicated that they are local area residents (the one remaining response was unclear). Respondents from Australia had visited the area and the GBR about seven times before on average compared to just one time for international visitors. Almost half of these were certified divers; close to one-fifth typed themselves as ecotourists; and about $10 \%$ were environmental scientists. Not surprisingly, then, almost a third of the sample took an overnight reef tour; approximately a fifth went to a pontoon/activity platform. About a fifth, also, went to one or more reefs. The most popular activity was snorkeling, following by viewing marine animals, taking a certified scuba dive to swimming.

Of the 87 people who specified which reef tour operator they used, Mike Ball Dive Expeditions was used by $19.5 \%$ of respondents, $16.1 \%$ used Sunlover Reef Cruises, 10.3\% Cairns Dive Centre, 9.2\% Tusa Dive and 8.0\% used Big Cat Green Island. Of the 92 people who answered the length of reef stay question, over one-fifth went on a reef tour that lasted four days or more; over half said it was a full day.

\subsubsection{Reef Experience}

Survey participants were asked to expand on their reef experience in an open-ended question by describing what was most memorable about it, what they found to be least enjoyable and what could have helped to improve their overall experience at the reef. An analysis of the responses received follows.

\section{Most Memorable Aspects}

A total of 171 responses were made by the 85 respondents who answered this question. The most frequently-mentioned memorable aspects and the percentage of respondents who made them were as follows: fish $(24.7 \%)$, "marine life" $(18.8 \%)$, coral (17.6\%), crew $(12.9 \%)$, sharks $(11.8 \%)$ and turtles $(10.6 \%)$. If we group together the experiential-type responses, we discover that $47.1 \%$ of respondents 
listed this as one of their most memorable aspects of their reef experience. If we add the mentions of less frequently stated marine life into the broader category, we find that "marine life" was mentioned by $36.5 \%$ of respondents. This figure is, of course, even higher if we add in sharks, turtles, etc.

\section{Least Enjoyable Aspects}

The least enjoyable aspects of visitors' reef experiences mentioned most often were none/not applicable $(23.5 \%)$, strong current $(9.9 \%)$, rough ride $(8.6 \%)$ and seeing poor health of the area, too many people on tours and travel to/from reefs (amount of time), all at 7.4\%. In all, 81 people answered this question and provided 98 responses. If we group together the responses related to water and weather conditions, we find that $33.3 \%$ of respondents listed this as one of the least enjoyable aspects of their reef experience. Combining responses related to the trip to the reef that were under the control of the operator, we discover that $27.2 \%$ of respondents gave such an answer. Given the relatively high percentage of such respondents, this should be of concern to operators.

\section{Improvements Needed}

A total of 80 respondents provided 92 responses as to what could be done to help improve their overall experience at the GBR. About one-third (33.8\%) of respondents said that nothing/not applicable was required to improve their experience. More educational information was mentioned by $11.3 \%$ of respondents. Better water conditions and fewer people on tours were both stated by $6.3 \%$ of respondents. Fifty percent of respondents would like to see such improvements made to better their GBR experience. Overall, however, it should be noted that over $60 \%$ rated their reef experience as "excellent"; about $30.0 \%$ rated it as "good", with the remainder rating it as "fair" or "poor".

\subsubsection{Visitor Learning}

The next section of the questionnaire focused on visitor learning. The questions asked in this section were designed to find out what visitors learned on their reef tour, where they obtained information, how they obtained it, if they were happy with how information was presented to them and if they would have liked to have learned more on their reef tour.

\section{Educational Presentation}

Survey participants were asked if the reef tour they took included an educational presentation on the boat about the GBR. Of the 94 who responded, $67.0 \%$ said their tour did include an educational presentation about the GBR; $27.7 \%$ said it did not; and the rest, $5.3 \%$, could not recall. Respondents who indicated that their reef tour did include such a presentation were then asked a series of questions about it. When asked to indicate when their presentation took place, $83.3 \%$ said "on the way to the reef"; $5.0 \%$ said "on the way back from the reef"; and 11.7\% said they could not recall. Next, respondents were asked if the presentation was live or recorded: $73.8 \%$ said the presentation they received was live; $14.8 \%$ said it was both live and recorded; $9.8 \%$ stated it was recorded; and 1.6\% could not recall; $87.3 \%$ stated that they listened to the presentation, while $11.1 \%$ said they did not, and $1.6 \%$ could not recall $(n=63)$.

People who stated that they listened to the presentation were then asked three questions about it. To begin with, they were asked to rate the presentation on four different aspects as listed in Table 1. For the purposes of ranking the items, mean scores were calculated where "poor" was assigned a value of one and "excellent" a value of four. As the table shows, all four aspects were rated highly with "knowledge of the presenter" being rated as "good" or "excellent" by $98.0 \%$ of the people answering the question. "Opportunity to ask questions" was the next highest rated aspect with $54.0 \%$ rating it as being excellent for the presentation they received. "Informative" and "interesting" were rated nearly as high as "opportunity to ask questions" with more people rating them as being "good" or "excellent" ( $92.2 \%$ and $94.1 \%$, respectively, versus $90.0 \%)$. 
Table 1. Presentation aspect ratings.

\begin{tabular}{|c|c|c|c|c|c|c|c|c|}
\hline Aspect & $n$ & Poor & Fair & Good & Excellent & $\begin{array}{l}\text { Don't } \\
\text { Recall }\end{array}$ & $\begin{array}{c}\text { Not } \\
\text { Applicable }\end{array}$ & Mean \\
\hline Knowledge of the presenter & 51 & $0.0 \%$ & $2.0 \%$ & $39.2 \%$ & $58.8 \%$ & $0.0 \%$ & $0.0 \%$ & 3.57 \\
\hline $\begin{array}{l}\text { Opportunity to ask } \\
\text { questions }\end{array}$ & 50 & $4.0 \%$ & $4.0 \%$ & $36.0 \%$ & $54.0 \%$ & $0.0 \%$ & $2.0 \%$ & 3.43 \\
\hline Informative & 51 & $0.0 \%$ & $7.8 \%$ & $45.1 \%$ & $47.1 \%$ & $0.0 \%$ & $0.0 \%$ & 3.39 \\
\hline Interesting & 51 & $0.0 \%$ & $5.9 \%$ & $49.0 \%$ & $45.1 \%$ & $0.0 \%$ & $0.0 \%$ & 3.39 \\
\hline
\end{tabular}

\section{Information Covered}

Next, people were asked to check off the types of information covered in the presentation they received (in addition to a list of eight items provided, they could add their own): $94.2 \%$ received information on "types of coral, fish, and other marine life", $82.7 \%$ on "responsible behavior" and $73.1 \%$ on safety. Of note, only $23.1 \%$ said they received information on climate change impacts on the reef (Table 2).

Table 2. Types of information covered in the presentation $(n=52)$.

\begin{tabular}{lcc}
\hline Information Type & Number of Respondents & $\begin{array}{c}\text { Percentage of } \\
\text { Respondents }\end{array}$ \\
\hline Types of coral, fish and other marine life & 49 & $94.2 \%$ \\
Responsible behavior (e.g., not touching corals, turtles) & 43 & $82.7 \%$ \\
Safety (e.g., wearing a life jacket) & 38 & $73.1 \%$ \\
Environmental threats and impacts to the Great Barrier Reef & 26 & $50.0 \%$ \\
Recreation and fishing activities at the reef & 16 & $30.8 \%$ \\
Climate change impacts on the reef & 12 & $23.1 \%$ \\
Maritime history of the area (e.g., explorers, history of coastal & 9 & $17.3 \%$ \\
communities, whaling history, etc.) & 3 & $5.8 \%$ \\
Aboriginal stories and relationship to the reef (past and present) & 6 & $11.5 \%$ \\
Other & & \\
\hline
\end{tabular}

More Information Desired

Lastly, people who listened to the presentation were asked if they would have liked to have had more information on any of the items mentioned in Table 2 and, if so, which ones. Forty-six-point-three percent would have liked to have had more information; $42.6 \%$ did not want more; and $11.1 \%$ did not know if they wanted more or not $(n=54)$. Of the 25 people who stated they would have liked to have had more information in the presentation they received on the boat, 24 indicated on what items they would have liked more information. The most frequently-mentioned items were "climate change impacts on reef" (75.0\%), "environmental threats and impacts to the Great Barrier Reef" (75.0\%), "aboriginal stories and relationship to the reef (past and present)" (66.7\%) and "maritime history of the area (e.g., explorers, history of coastal communities, whaling history, etc.)" (50.0\%). The complete breakdown of responses to this question is provided in Table 3.

Table 3. Types of additional information desired from onboard presentation $(n=24)$.

\begin{tabular}{lcc}
\hline Information Type & $\begin{array}{c}\text { Number of } \\
\text { Respondents }\end{array}$ & $\begin{array}{c}\text { Percentage of } \\
\text { Respondents }\end{array}$ \\
\hline Climate change impacts on reef & 18 & $75.0 \%$ \\
Environmental threats and impacts to the Great Barrier Reef & 18 & $75.0 \%$ \\
Aboriginal stories and relationship to the reef (past and present) & 16 & $66.7 \%$ \\
Maritime history of the area (e.g., explorers, history of coastal & 12 & $50.0 \%$ \\
communities, whaling history, etc.) & 10 & $41.7 \%$ \\
Types of coral, fish, and other marine life & 6 & $25.0 \%$ \\
Recreation and fishing activities at the reef & 4 & $16.7 \%$ \\
Responsible behavior (e.g., not touching corals, turtles) & 2 & $8.3 \%$ \\
Other & & \\
\hline
\end{tabular}


The two comments mentioned under "other" in Table 3 are as follows:

- Weather anomalies and up-to-date marine information to strengthen public awareness.

- Difficult to say as we could not hear much what was said, but maybe environmental threats.

Respondents were also asked to comment on the onboard presentation, of which only three did so, as follows (direct quotes):

- The "Reef Daytripper" did have two books of photographs showing many corals and fish but I think that the "Reef Teach" before a trip would be excellent.

- The marine biologist was very knowledgeable.

- I think generally there isn't enough attention given to the relationship between Traditional Owners and their relationship to wildlife/reef. Obviously, it isn't appropriate for non-Indigenous people to talk about some elements but employing Indigenous people or working collaboratively with Indigenous people to share knowledge is important.

In order to gain more information on whether or not these visitors to the GBR are interested in learning about the history, environment and culture of the area, they were asked whether, if given a choice, they would prefer a tour that covered those aspects or a tour that did not cover them. They were told the overall aspects of the tours would be the same. Respondents overwhelmingly $(89.7 \%)$ indicated they would prefer to take a tour that includes talks about the history, environment and culture of the area $(n=87)$.

\subsubsection{Where Else Respondents Learned about the Great Barrier Reef during the Reef Trip}

All survey participants were asked to indicate where else they learned about the GBR during their reef trip. They were provided with a list of 11 typical scenarios and could also add in their own if needed. The most common response was that they learned about the GBR by talking to staff or the skipper on the tour boat. This was mentioned by $53.5 \%$ of the 86 people who answered this question. Nearly half (48.8\%) said they learned about the GBR from printed information. Survey participants were also asked if they took a "Reef Teach" course in Cairns during their trip to the area (Reef Teach is a small organization in Cairns offering informative presentations about the GBR). Of the 88 people who answered the question, 17 respondents (19.3\%) said they did, and the remaining $71(80.7 \%)$ said they did not.

\subsubsection{Environmental Threats, Impacts and Action}

The focus of the survey then shifted to environmental threats and climate change impacts that are occurring in the GBR in the Cairns/Port Douglas area. The goal of this section was to ascertain how visitors perceive these threats and who they thought should be responsible for taking action to minimize them.

Respondents were asked to rate the level of threat to the GBR from each of nine impacts presented to them. In order to rank the impacts, mean scores were calculated for each item by assigning a score of one to "none" on up to a score of four for "very serious". As can be seen from Table 4, the top three threats are "increased shipping lanes through the GBR", "oil spills" and "climate change", which were rated as "very serious" threats by $58.6 \%, 58.1 \%$ and $57.0 \%$, respectively. All nine impacts were rated as "somewhat serious" or "very serious" by $50 \%$ or more of the respondents who replied to this question. Of note, just $3.5 \%$ of respondents rated the threat from climate change to the GBR as "none" or "minimal". 
Table 4. Level of threat to the GBR from various impacts.

\begin{tabular}{|c|c|c|c|c|c|c|c|}
\hline Impact & $n$ & None & Minimal & $\begin{array}{l}\text { Somewhat } \\
\text { Serious }\end{array}$ & $\begin{array}{l}\text { Very } \\
\text { Serious }\end{array}$ & $\begin{array}{l}\text { Don't } \\
\text { Know }\end{array}$ & Mean \\
\hline $\begin{array}{l}\text { Increased shipping lanes through } \\
\text { the GBR }\end{array}$ & 87 & $2.3 \%$ & $4.6 \%$ & $21.8 \%$ & $58.6 \%$ & $12.6 \%$ & 3.57 \\
\hline Oil spills & 86 & $1.2 \%$ & $5.8 \%$ & $25.6 \%$ & $58.1 \%$ & $9.3 \%$ & 3.55 \\
\hline Climate change & 86 & $2.3 \%$ & $1.2 \%$ & $34.9 \%$ & $57.0 \%$ & $4.7 \%$ & 3.54 \\
\hline Overfishing & 86 & $3.5 \%$ & $4.7 \%$ & $30.2 \%$ & $50.0 \%$ & $11.6 \%$ & 3.43 \\
\hline Deteriorating water quality & 86 & $1.2 \%$ & $10.5 \%$ & $31.4 \%$ & $45.3 \%$ & $11.6 \%$ & 3.37 \\
\hline Crown of thorns starfish & 85 & $2.4 \%$ & $14.1 \%$ & $28.2 \%$ & $38.8 \%$ & $16.5 \%$ & 3.24 \\
\hline Farming & 84 & $0.0 \%$ & $10.7 \%$ & $46.4 \%$ & $31.0 \%$ & $11.9 \%$ & 3.23 \\
\hline Tropical cyclones & 86 & $2.3 \%$ & $30.2 \%$ & $27.9 \%$ & $29.1 \%$ & $10.5 \%$ & 2.94 \\
\hline
\end{tabular}

\subsubsection{Level of Responsibility of Entities to Address GBR Environmental Threats}

Next, survey participants were asked to indicate how responsible they feel each of eight entities, including themselves, should be for addressing environmental threats to the GBR. Once again, mean scores were calculated for each entity in order to rank the responses received. A score of one was assigned to "not at all responsible" up to a score of five for "completely responsible". Studying the results presented in Table 5, it is clear that people feel the Australian national and Queensland state governments should be the most responsible for addressing environmental threats to the GBR. These two levels of government should be either "mostly responsible" or "completely responsible" according to $87.3 \%$ and $87.4 \%$, respectively. The tourism industry was seen to be the third most responsible entity with 73.5\% stating that it should be "mostly" or "completely" responsible. Nonprofit groups were viewed as being the entity that should be held responsible the least for dealing with environmental threats to the GBR, with just $21.6 \%$ saying that they should be "mostly" or "completely" responsible for addressing environmental threats to the GBR. Over half of the respondents felt that they themselves had to assume some level of responsibility: a third felt somewhat responsible to assist; and over half felt strongly responsible (ranging from mostly responsible to completely responsible). See Table 5 for exact breakdowns.

Table 5. Level of responsibility for various entities to help address environmental threats to the GBR.

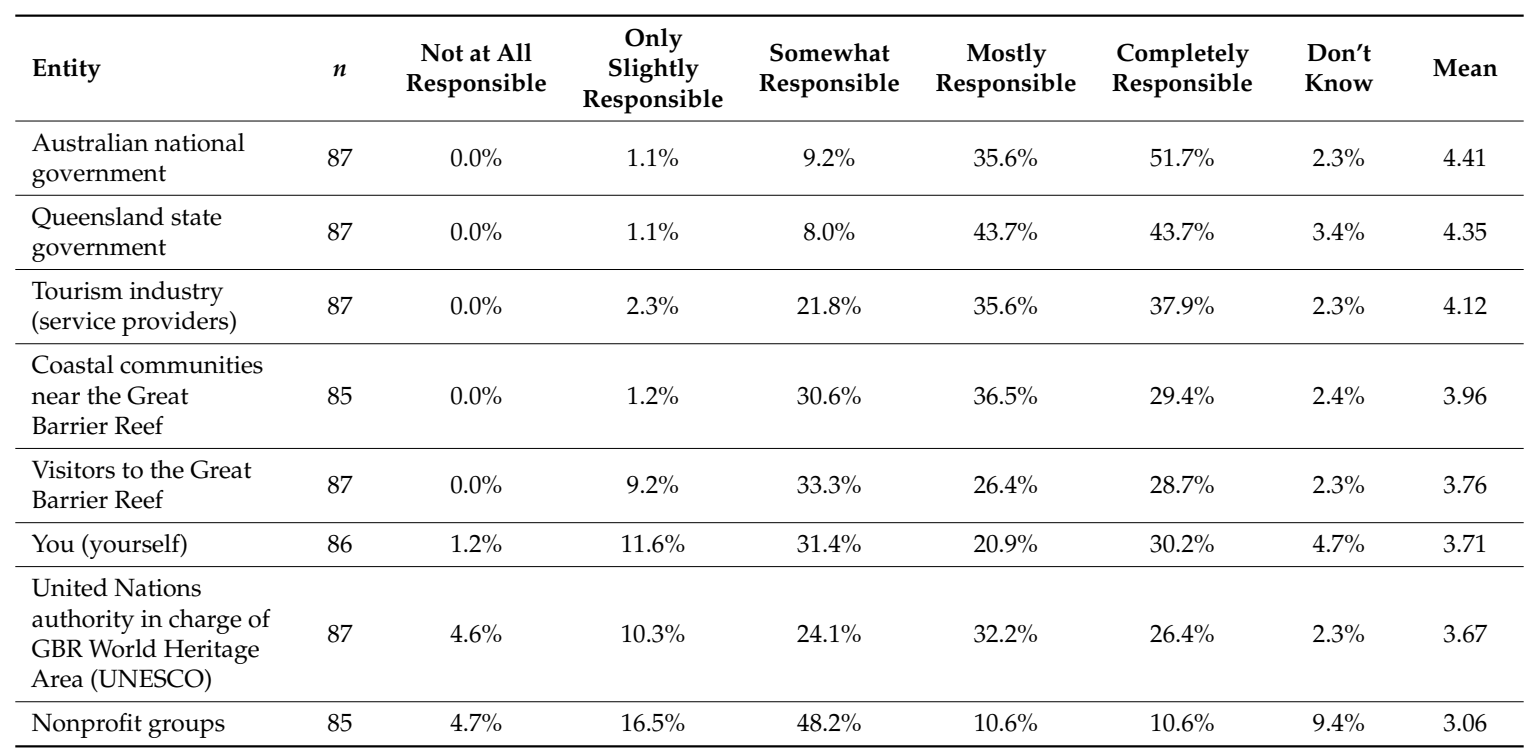




\subsubsection{Desire to Learn More about Environmental Threats to the GBR and Where}

Survey participants were asked if they would have liked to have learned more about environmental threats to the GBR during their visit. Sixty-four respondents (70.3\% of the 91 people who responded to the question) said they would, and 27 (29.7\%) said no. People who said they would have liked more information were then asked to indicate when they would have liked to have received it in relation to the timing of their trip. They were presented with five different time frames and could choose as many of them as they wanted. Table 6 indicates that of the 64 people who would have liked to have learned more about the environmental threats to the GBR, 64.1\% would have liked more information provided to them during their reef tour, $43.8 \%$ before they arrived, $32.8 \%$ when they arrived, $9.4 \%$ right after their reef tour and $6.3 \%$ when they returned home.

Table 6. When one would have liked to have obtained more information $(n=64)$.

\begin{tabular}{lcc}
\hline When & $\begin{array}{c}\text { Number of } \\
\text { Respondents }\end{array}$ & $\begin{array}{c}\text { Percentage of } \\
\text { Respondents }\end{array}$ \\
\hline During my reef tour & 41 & $64.1 \%$ \\
Before I arrived & 28 & $43.8 \%$ \\
When I arrived & 21 & $32.8 \%$ \\
Right after my reef tour & 6 & $9.4 \%$ \\
When I returned home & 4 & $6.3 \%$ \\
\hline
\end{tabular}

\subsubsection{Desire to Learn More about Actions Being Taken to Minimize Impacts on the GBR}

When asked if they would have liked to have learned more about what actions various groups are taking to minimize negative impacts on the reef, $83.9 \%$ said they would have liked to have had more information on this topic about their reef tour operator's role. Table 7 also shows that the corresponding figures were $82.8 \%$ for the tourism industry, $75.9 \%$ for the Queensland state government, $71.3 \%$ for the Australian national government and $47.1 \%$ for their accommodations provider.

Table 7. Desire to learn more about actions taken by various groups to minimize negative impacts on the GBR.

\begin{tabular}{|c|c|c|c|c|}
\hline Entity & $n$ & Yes & No & Not Sure \\
\hline Your reef tour operator & 87 & $83.9 \%$ & $10.3 \%$ & $5.7 \%$ \\
\hline $\begin{array}{l}\text { Tourism industry (i.e., tour operators, } \\
\text { accommodations providers, restaurants, etc.) }\end{array}$ & 87 & $82.8 \%$ & $12.6 \%$ & $4.6 \%$ \\
\hline Queensland state government & 87 & $75.9 \%$ & $11.5 \%$ & $12.6 \%$ \\
\hline Australian national government & 87 & $71.3 \%$ & $16.1 \%$ & $12.6 \%$ \\
\hline Your accommodations provider & 85 & $47.1 \%$ & $37.6 \%$ & $15.3 \%$ \\
\hline
\end{tabular}

\subsubsection{Concern and Action on Climate Change}

Eighty-five people responded to the question asking how concerned they are about climate change. $43.5 \%$ said they are "very concerned", with another $29.4 \%$ indicating that they are "fairly concerned". At the other end of the scale, $11.8 \%$ are "not very concerned"; $7.1 \%$ are "not at all concerned"; and $11.8 \%$ are "not very concerned". Of the remaining, 5.9\% "do not know" and $2.4 \%$ have "no opinion". Respondents were also presented with seven statements on climate change and asked to state to what degree they either agreed or disagreed with each one. Mean scores were calculated for each statement in order to rank the results where a score of one was assigned to "strongly disagree" up to a score of five for "strongly agree". The statement with the most agreement from respondents was clearly "I feel it is important to address climate change impacts on the Great Barrier Reef" with $87.4 \%$ indicating that they "tend to agree" or "strongly agree" with it. In fact, $57.5 \%$ said they "strongly agree" with the statement. The only other statement to have more than $50 \%$ either saying they "tend to agree" or "strongly agree" with it was "I am certain that climate change is really happening". For four of 
the statements, over half of the respondents disagreed with them to some extent. Exactly $71.0 \%$ of respondents either "strongly disagreed" or "disagreed" with the statement "there is enough common sense and goodwill in society to prevent climate change having any serious impact" (Table 8).

Table 8. Level of agreement on various statements about climate change.

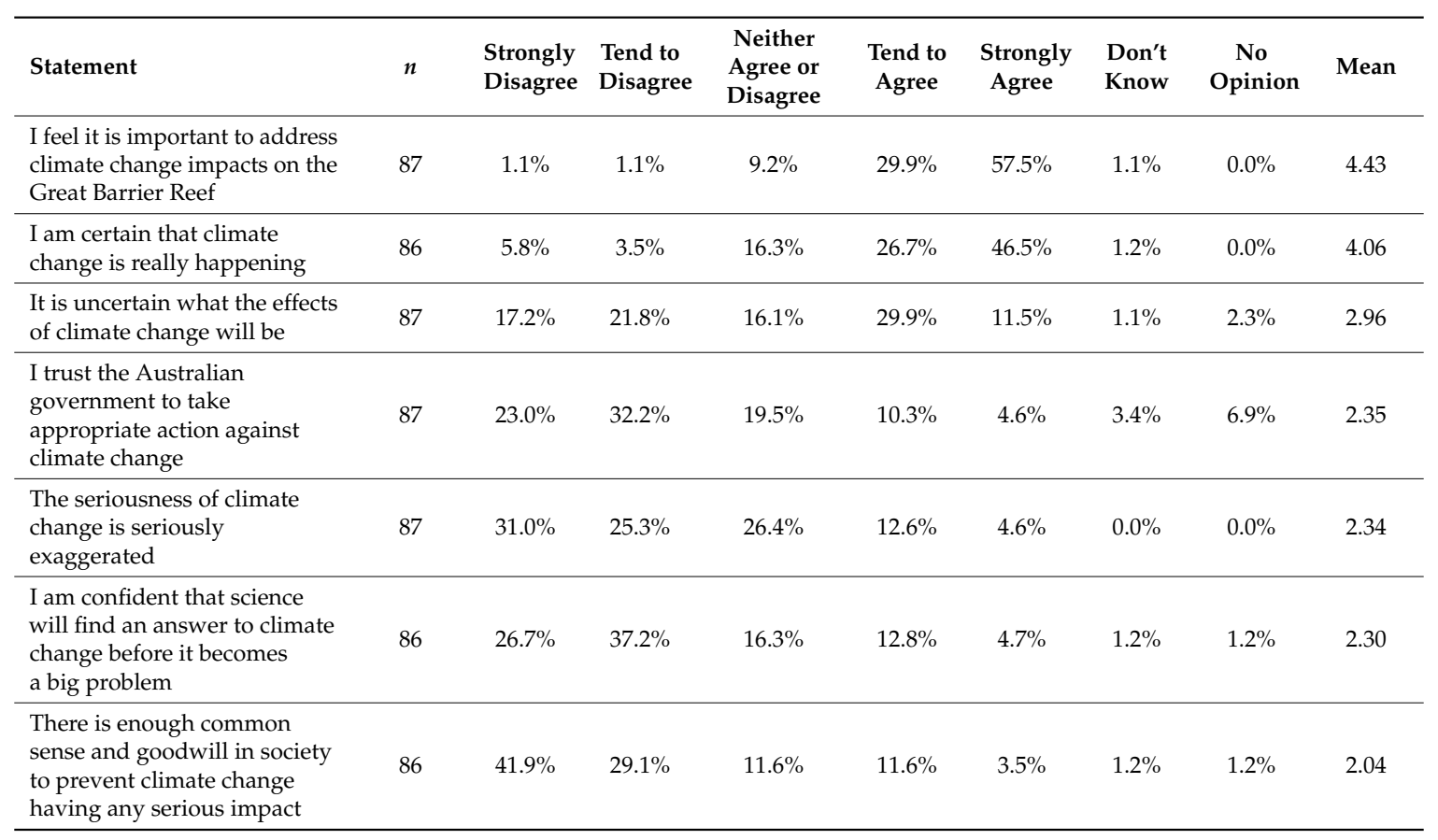

\subsubsection{Climate Change Perceptions}

Respondents were presented with six statements and asked to indicate which one best describes their opinion in terms of what they think about the causes of climate change. They could also answer "do not know" or "no opinion". Exactly $46.0 \%$ chose "climate change is partly caused by natural processes and partly caused by human activity" and 32.2\% selected "climate change is mainly caused by human activity". Just one person out of 87 believes that there is no such thing as climate change. When asked to state how informed they feel about climate change issues in the GBR, 27.6\% said they were "informed", and $12.6 \%$ "very informed". Despite the huge and longstanding presence of this issue in the media, eight (9.2\%) indicated that they felt "very uninformed", $24.1 \%$ "uninformed" and $23.0 \%$ "neither informed nor uninformed" on these issues. The remaining 3.4\% said they did not know how informed they were $(n=87)$.

\subsubsection{Visitor Action}

The last section of the survey contained one question that asked people which of four different entities they might be more inclined to contact on two matters related to the GBR now that they have visited it. The first matter dealt with climate change impacts on the GBR. Of the 60 people who provided a response on this matter, $80.0 \%$ said they would be more inclined to email, write or petition the Australian government. Likewise, $71.7 \%$ said they would be more inclined to contact the Queensland government, $48.3 \%$ reef tour operators and 40.0\% UNESCO. The second matter pertained to the conservation of the GBR. The corresponding figures for this matter with a subsample size of 59 are $78.0 \%$ would be more inclined to contact the Australian government, $74.6 \%$ the Queensland government, $62.7 \%$ reef tour operators and $47.5 \%$ UNESCO. The results for this question are shown in Table 9. 
Table 9. More inclined to contact entities on matters related to the GBR.

\begin{tabular}{lcc}
\hline Matter & $\begin{array}{c}\text { Number of } \\
\text { Respondents }\end{array}$ & $\begin{array}{c}\text { Percentage of } \\
\text { Respondents }\end{array}$ \\
\hline Climate Change Impacts on the GBR $(n=60)$ & & \\
Australian Government & 48 & $80.0 \%$ \\
Queensland Government & 43 & $71.7 \%$ \\
Reef Tour Operators & 29 & $48.3 \%$ \\
UNESCO & 24 & $40.0 \%$ \\
Conservation of the GBR $(n=59)$ & 46 & $78.0 \%$ \\
Australian Government & 44 & $74.6 \%$ \\
Queensland Government & 37 & $62.7 \%$ \\
Reef Tour Operators & 28 & $47.5 \%$ \\
UNESCO & & \\
\hline
\end{tabular}

\subsubsection{Qualitative Responses}

At the very end of the survey was a space for participants to offer any further comments related to their reef experience or to matters raised on the survey. Forty-two participants offered comments on the survey: 29 respondents were from Australia (13 of these were from Queensland), seven from the U.S., three from the U.K., one from China, one from Canada and one from South Africa. Respondents are identified below by a respondent ID number and non-Australian voices are noted. The comments ranged from short praises of some reef operator and pleasurable experiences, to concern and the need for visitor education, awareness raising and conservation actions. Underlined text indicates items of direct interest to the study. Enjoyment, as well as learning about the reef, for instance, are evident in the following:

The reef teach course I took prior to our trip was the most helpful in educating me, I was able to identify many of the species of fish and coral that I saw on the trip. (44, U.S. visitor)

I think more education about the topics in this survey is critical for gaining more international support. Tours like this are how people from other parts of the world start to understand and get involved. Once they've experienced the Reef firsthand, it becomes much more real to them. (16)

As I have not been to the Great Barrier Reef before I had nothing to compare the condition of the [reef] to apart from reefs of Fiji many years ago. I found the Great Barrier Reef to be equal to those reefs and was surprised by the abundant colors of the coral and fish. I would highly recommend the tour I took to family and friends and hope to go again myself. (65)

The more that can be done the better so that future generations are able to enjoy this amazing natural structure. (1)

This visitor links memorable experience, appreciation and the need to be responsible:

It was a memorable experience and a newfound appreciation for the need to preserve it and be socially responsible. (72)

Climate change was mentioned a couple of times, once with urgency and noting lack of knowledge. Other threats to the reef were commented on frequently, including over-fishing, shipping lanes, concern about dredging, increased shipping and other commercial activity, as well as traditional cultural practices. For instance:

I think that it is very important to improve conservation of the Great Barrier Reef.... I find that many people do not know the serious nature of climate change and how dangerous the acidification of the ocean as caused by increased $\mathrm{CO}_{2}$ in the atmosphere to the health of reefs. (51, U.S. visitor) 
I am EXTREMELY concerned to hear of proposed dredging of the reef for more expansive, deep shipping and/or oil drilling. This would be far too damaging to the Great Barrier Reef and should be stopped with methods that permanently block this type of proposal. (35, Canadian visitor)

I independently "tweeted" after our visit that if anyone is a climate change skeptic, they could be cured by going to the reef and Daintree. (42)

Re climate change, it is in my opinion too much of a fad. Fixing the known issues of fertilizers, development impacts and general over consumerism/materialism are harder to articulate but fundamental to humans trashing their globe. (61)

Climate change is a long-term issue. The more immediate issues for the health of coral reefs are land sourced pollution, dredging and over-fishing. (61)

Although having only made about 4 dive trips to the GBR my stays have been lengthy and my diving extensive ... snorkeling and diving the "yellow and blue zones" has left me no doubt that the Great Barrier Reef is over fished ... The "green zones" must be increased ... sharks should be given far more protection ... Increasing shipping traffic concerns me a great deal too ... it is wrong ... that indigenous people are allowed to fish the green zones and hunt endangered animals such as turtles and Dugongs ... What is at stake here is not someone's culture but the future health of the Great Barrier Reef and its inhabitants. Once it's gone it's gone forever, and that will affect us all! (85)

Adverse visitor impacts and the need for action (including regulation and taxing) and information (e.g., by reef operators) is noted by a good number of respondents, such as:

The group I travelled with and myself thought that it was odd that nobody really mentioned how dead the reef is. There was also minimal security on the tourists. People were touching coral and chasing fish. We even saw one guy grab a turtle and try to turtle surf...I think there should be harsher consequences to tourists willing to damage the reef. (24)

Reef operators should stress more to be careful with the coral while diving and snorkeling. Lots of tourists stand or walk with their big fins straight over the coral and do a lot of damage. (57)

I don't think that enough information is given to tourists in language that they can understand about the localized impacts of their visit as well as the global impacts on coral reefs. (59)

As a member of the $[X X]$ Foundation, I was interested in the environmental issues related to the Great Barrier Reef. I was surprised there was not more educational information on the reef trip. (21, U.S. visitor; XX denotes foundation name withheld for privacy purposes)

There are so many tour operators especially in Cairns going to the reef that it is hard to understand how all those people and boats are not having a negative impact on the reef.... Visitors trust that the company they are taking a tour with, and the government and other responsible bodies are managing the impacts appropriately and a suitable level. After all, we are in a "developed" country ... At the moment I cannot see a way to tell the difference between the operators ... People want to enjoy their trip to the reef, but should they be picking up sea cucumbers, or trying to stroke the fish, swimming behind turtles, or kicking the coral? (58, U.K. visitor) 
I do believe that if not already in place, motorized dive boats operating day dive trips out of Cairns should be restricted to specific areas. Inexperienced divers tend to crash into and damage the Reef and should be assigned to areas where damage can be contained. (78, South Africa)

...major shipping should not be allowed to traverse inside the reef ... Companies should be taxed on all produce that is exported through or via the reef and all of that money should be put into research and rehabilitation of the reef. Run off from the land caused by development should be contained and again the developers taxed or fined for any excess run off from their activities. There was little information about the reef and the effects of climate change and development on the reef to be found in Cairns, if there was it was not readily available, should be more promotion about reef life and sustainability. (23)

Concern and care about, as well as for, the reef is evident in the voices of many respondents. Awareness by divers and awareness raising by a local dive company, as well as concern about visitor impacts is noted here by a scuba diver, who spends time in close proximity and teaches students about the reef:

I felt the people on Mike Ball did a very good job about reef conservation awareness. I personally feel that divers tend to be a bit more savvy about taking care of the reef and our oceans. As a scuba instructor, I talked about it with all my students as I believe most scuba instructors do. It's the casual vacation snorkeler or resort course diver that scare me with their touching and taking from the oceans. (79, U.S. visitor)

This diver quoted below works in the dive industry in close proximity with the reef (has done "hundreds of dives" at the GBR) and felt that "losing such an iconic, impressive, and diverse ecosystem would be a travesty". The impact of runoff from farms and cities along Australia's East Coast was this diver's "personal greatest concern". Tourists tended to misdiagnose what constituted damaged or dying reef, or what appeared to be coral bleaching, felt this diver; reef education should be fun and informative, but threats should not be covered greatly:

If reef education is to happen, it should be done in a fun and informative way, including the history of the reef and how it has formed, how reefs grow, the different ecosystems within the reef itself, animal behaviors, and symbiotic relationships. What shouldn't be covered in great detail are environmental threats, as this tends to turn people off. Whether it is shark finning, whaling, or climate change, it doesn't matter. Reef trips should foster an understanding and appreciation for the reef, but shouldn't be a pulpit for people to preach about threats (over-exaggerated or not). (83)

Concern about sensationalizing, exaggeration and negative publicity were expressed by a couple of respondents, who also raised concern about other threats to the reef's health:

Put the real threats into real perspective, don't sensationalize and create hype, create "S.M.A.R.T." solutions. (74)

It would appear that the most recent scientific papers describing the GBR condition are exaggerated ... The care and zone protection in place is clearly improving the condition of the GBR. As a frequent visitor to many sections of the reef over the last 30 years I have witnessed massive improvements in marine life and prolific coral growth as a result of zoning. We need to reduce large shipping inside the GBR and send them outside to transit... (66) 
Care, responsibility and the need for conservation action were mentioned in several responses, but as the participant below noted, what actions ought to occur at the individual level (rather than at the level of the reef operator, or state/federal government, as the first quote below mentions) were not evident:

I'm concerned that there is too little action taken by state and federal government to protect the reef and would hate to see the situation of "too little too late". I support any actions taken to protect environments, including and especially the Great Barrier Reef.

I'm completely in favor of preserving the reef and marine life, but not clear what I as an individual can do. Not personally convinced that humans are causing the oceans to become warmer, but am convinced that excessive fishing and shark kills are very detrimental. (87, U.S. visitor)

I think it is very important to protect the reef and feel that people need to do their best to do their part. I am not completely sure what improvements can be made though. Maybe more pictures of healthy habitats compared to unhealthy ones. I do believe that people do care but people are very lazy. (90, U.S. visitor)

This rich quote below expresses concern about the reef's health and the respondent's children being able to experience, politically-driven development pressures and the reactive governance action Crown-of-Thorn starfish (COTS) eradication program:

I think the Great Barrier Reef is in for some tough times ahead with wall to wall liberal governments and their push for development at all costs. Not to mention the reactive nature of the COTS eradication program. The current COTS outbreak was predicted after the last cyclone event 3 years ago and the Federal and State governments are now playing catch up. I am getting my kids out to reef while it is still in relatively good shape because I don't think the kids will have much of a chance to experience it. (59)

The visitor below demonstrates both increased awareness and learning through reef and marine experiences, as well as active efforts to stay informed and take actions on key issues of concern, including writing, voting, staying informed, etc., and hopes to be able to share the reef's enjoyment with the children ("nieces and nephews"):

I really learned a lot while I was on my last trip and have over years of undertaking ecotourist marine adventures. Tourist activities such as swimming with the minke whales have really heightened my understanding of issues of marine conservation and I share these with others, write letters, vote appropriately and keep myself informed about them. Certainly key issues such as the impact of farming, mining, shipping, over-fishing, global warming and tourism on the Great Barrier Reef are extremely important to me and I will continue to fight for these things including making informed decisions at the upcoming election. I want to know that the twenty years or so of activities I have been enjoying the GBR so far are things I can share with my nieces and nephews when they get older. (34)

\section{Discussion}

This article addresses the potential for globally-significant places like the GBR to provide visitor experiences that are not only enjoyable and memorable in terms of the recreation and enjoyment of the reef's ecological wonders, but also valuable with respect to facilitating greater environmental literacy, awareness and civic engagement in environmental sustainability and climate change. As Slocum [58] (p. 433) stated: "Localizing climate change means to transform it into problems that are materially and culturally relevant to citizens and also to change what is relevant". The exploratory Great Barrier 
Reef survey shows a generally well-educated sample of visitors (Australian $60 \%$ and international visitors $40 \%$ ) who are overall aware and concerned about climate change impacts on the reef. Their reef experiences and open-ended comments show interest in receiving knowledge and information on the reef overall, as well as on climate change impacts on the reef. For example, of people who listened to an on-board reef presentation, over half (54.0\%) rated the "opportunity to ask questions" as being "excellent". However, just $23.1 \%$ indicated that they received information on climate change impacts on the GBR, and of the respondents who said they would have liked additional information during the presentation, $75.0 \%$ said they wanted more information on climate change impacts on the reef with the exact same percentage saying they wanted further information on environmental threats and impacts to the GBR. Including people who did not listen or have an on-board presentation, about $70 \%$ of respondents would have liked to have learned more about the environmental threats to the GBR as part of their visit either before, during or after their trip.

It should also be noted that nearly $90 \%$ would prefer a reef tour that included talks on the history, environment and culture of the area over one that did not. Two-thirds of the respondents wanted more information on aboriginal stories and their past and current relationship with the reef. These stories could be used to facilitate enjoyment and learning of the reef's cultural history and social context, enhancing the aesthetic experience that is vital to foster a good "reef ethic" (following from Leopold's land ethic discussed earlier). High interest by respondents on learning more about the reef's environmental, social and cultural heritage, as well as interest in learning more about environmental threats to the reef suggest that the reef operators are missing an important opportunity to enrichen visitor experience and facilitate conservation with the help of this important stakeholder group. Some reef stakeholders (including operators and visitors; see open-ended respondent comments above) expressed concern about talking about climate change and reef threats as the media already painted a negative image of the reef's problems, and adding more might detract international visitors. However, surely such environmental knowledge can be combined with affective, enjoyable experiences (following Aldo Leopold and John Dewey as discussed earlier) to facilitate experiential learning and both personal and civic action (adoption of conservation behavior, democratic engagement in forwarding environmental policy changes, etc.)?

Destination managers and experience providers need to view destinations such as the GBR as pedagogic sites for responsible enjoyment and learning. Following Leopold and Dewey democratic pedagogy, rich experiential learning can help facilitate climate literacy, global environmental citizenship and social action. Both Leopold and Dewey advocate a democratic environmental and social ethic respectively where experiential education and environmental literacy is not sufficient without responsibility for follow-up action. In the context of the GBR, it can be argued that all stakeholders, including domestic and international visitors, must take on the responsibility to act for its conservation and sustainability for present and future generations, for the reef is valued intrinsically by residents and visitors (see quotes) and is designated as a World Heritage Area of great ecological and significance. The GBR survey reveals significant inclination for tourists to engage in political action after their reef visit, to contact policy makers to address environmental threats to this iconic global heritage, valued for its ecological and social importance, and to enjoy and learn about its ecological treasures, social uses and cultural heritage. Over $87 \%$ of the visitors stated that they either "tend to agree" or "strongly agree" that it is important to address climate change impacts on the reef. Both proximity and stakeholder ability to influence change and conservation are evident in their responses. Eighty percent of survey respondents indicated that they themselves would be willing to take responsibility to either email, write or petition the Australian national government on their concern about climate change impacts on the reef. The corresponding figures for the Queensland government, reef tour operators and UNESCO are $71.7 \%, 48.3 \%$ and $40.0 \%$, respectively.

Visitor responses also expressed a strong desire to learn more about the actions various groups are taking to minimize negative environmental impacts to the reef overall. This figure was over $80 \%$ when it pertained to what reef operators and the tourism industry are doing. Research on multi-stakeholder 
responsibility for social action and societal change is also critically needed, on the supply side, as well as on the part of the traveling public. Our study participants ranked the national and state governments as most responsible for addressing environmental threats to the GBR, followed by the tourism industry and local coastal communities. The Australian national and Queensland state governments were each seen by about $87 \%$ of respondents as the entities that should be either "mostly responsible" or "completely responsible" for addressing environmental threats to the GBR. The corresponding figure for the tourism industry was $73.5 \%$. The open-ended comments from survey participants corroborate proximal responsibility, with several respondents noting the need for greater reef regulation and conservation by the Australian government, as well as impact management and education of tourist by reef tour operators (a range of reef impacts being caused by tourists, as well as other stakeholders was noted). These results support the argument forwarded in our earlier discussion on the "reef ethic", with respect to responsibility and action by proximal stakeholders and those most able to engage in reef conservation and climate action (see the two prima facie claims about responsible parties stated earlier; also, see below). They include key stakeholders in the reef tourism system: the Australian government and reef tour operators.

Survey respondents not only identify the important responsibility of the state and federal government to act on numerous conservation matters, but also their own role and responsibility for encouraging conservation action. The percentage of visitors willing to either email, write or petition various entities addressing the overall conservation of the GBR are as follows: Australian government $(78.0 \%)$, Queensland government $(74.6 \%)$, reef tour operators $(62.7 \%)$ and UNESCO $(47.5 \%)$. Interestingly, over half the visitors surveyed felt tourists held great responsibility to help address environmental threats to the GBR. This would constitute new and emerging roles for tourists that bear further research and investigation: the role of area-based and international visitors in engaging in responsible social and political actions for sustaining the GBR for future generations. A clear picture emerges from the above results of the pedagogic role and potential of tourism to foster global environmental literacy and civic action to address environmental threats and conservation of destinations of immense environmental value and cultural heritage significance to civilization. The awareness, knowledge and interest of GBR reef visitors to learn about the destination and environmental threats to the GBR and to learn about what actions are being undertaken by key stakeholders including reef tour operators and the government, plus their willingness to bear and ascribe responsibility, break new ground in situating the powerful role of tourism for pedagogy and responsible social action. The small, but robust exploratory study of GBR reef visitors corresponds well with the "reef ethic" discussion forwarded earlier in the article.

It should be noted here that encouraging ethical action requires continuity in sustainable and responsible environmental stewardship at home and in the holiday space (building good sustainability habits does not stop on holiday or at home); facilitating continuity in ethical action and behaviors between home and the holiday space is essential to avoid cognitive and psychological dissonance (see [59]). Targeted education and communication about climate change along with concrete, doable ethical practices at the destination, as well as after the visitors arrive back home may be a valuable direction for future research and practice (see [27], as well).

\section{Directions Forward}

Our article tackles challenging issues of ethical and practical significance for tourism studies and the sustainability of globally significant destinations such as the GBR. It has been argued here that world heritage places like the Great Barrier Reef should be seen as pedagogic spaces for aesthetic encounters, facilitating enjoyment, experiential learning and promoting democratic responsibility and climate action for the conservation and sustainability of these iconic places. The GBR survey results support the potential and need for awareness raising, knowledge building and collaborative involvement of various stakeholders including tourists and the Australian state and federal government (by proximity as stewards of the reef, as well as by political power; note that 
UNESCO ranks below the Australian/Queensland government and reef tour operators in terms of entities the respondents were willing to contact).

The interest expressed by the GBR study visitors in learning and increasing their awareness about the reef and environmental threats it faces, recognizing their own roles and responsibilities toward conserving the reef, suggest that protected area destinations of national and global significance can play a vital role in climate change pedagogy and facilitating informed political action. Increased global environmental literacy in a traveling public enables an informed global citizenry that should help to generate public support for legislative and policy initiatives to address climate change impacts in protected areas of global significance. As such, global heritage destinations like the Great Barrier Reef offer a common ground for businesses and citizens locally and globally to think in different ways about themselves in relation to home and globally, as global citizens willing to take responsibility and engage in social action and civic action to address issues of common concern (e.g., climate change, global world heritage sites like the GBR; see also [60]). As environmental attitudes, social sentiments and political discourses shift dynamically cross-culturally at home and worldwide (see [61]), proactive planning, policy making and other conservation-related actions by destination managers and service providers will be increasingly important [56]. A sustainable tourism pedagogy is needed that facilitates knowledge and awareness raising among the stakeholders of tourism and climate change, as well as civic responsibility and social action; it is a democratic pedagogy following Aldo Leopold and John Dewey, as sketched out earlier.

Previous research has identified important awareness raising strategies such as targeted communication and social marketing, in addition to experiential education and interpretive programs by tourism experience providers, that can facilitate environmental literacy and joint democratic actions [62-66]. Further research is clearly needed on the sociocultural, political and ethical dispositions of domestic and international visitors in relation to climate change and direct (civic) action to conserve areas of global significance like the Great Barrier Reef (see [67-69]). The luxury of decades to influence attitudes and behaviors with respect to climate change may not be available at the rate of environmental change being experienced in such unique spaces of global significance, identity and meaning for human civilization [33]. To dwell as a society is to dwell with the Great Barrier Reef as a marvelous biophysical wonder to appreciate, study and conserve, nurturing its multitudes of species and habitats, its economic benefits, as well as its rich cultural heritage of human inhabitation and visitation. Imbricated with national and global heritage, it symbolizes what it means to be the human race as much as what it means to be an Aussie or a diver at the reef, a coastal community or an indigenous dweller. They are pedagogic destinations for enjoyment, care and conservation through the learning and opportunities they offer for global environmental literacy, citizenship and responsible action by visitors and other key stakeholders.

Acknowledgments: Sincere thanks to Susanne Becken, Griffith Institute for Tourism (GIT), Griffith University, Australia, for funding support, advice and feedback on the GBR survey and this article. The study was funded by Griffith University as part of their visiting academic program. Additionally, we would like to acknowledge The Cairns Institute, Australia, and Bruce Prideaux (then with The Cairns, Institute, James Cook University, Australia) for support and assistance in implementing the survey. We are also grateful to Linda Radzik, Philosophy, Texas A\&M University, USA, for assistance in thinking through the steps (reasoning) in Section 2.2, related to valuing and caring for the reef, responsibility for conserving the reef, plus the two prima facie claims contained there. As Radzik pointed out, the ought-can distinction in philosophy is an important consideration here, for if a person does not have the means to engage in an ethical action being called upon to do, then an "ought" cannot be prescribed (e.g., you ought to conserve the reef). Our thanks also to the local tour operators and staff who assisted with handing out the survey "postcards" and to all of the survey participants, especially.

Author Contributions: Both authors contributed equally to this work.

Conflicts of Interest: The authors declare no conflict of interest. 


\section{References}

1. Cummings, A.; Westcott, B. Great Barrier Reef 'Cooking and Dying' as Seas Heat up, Warn Scientists. Available online: http:/ /www.cnn.com/2017/04/10/asia/great-barrier-reef-coral-bleaching/index.html (accessed on 15 April 2017).

2. IUCN (International Union for Conservation of Nature). IUCN World Heritage Outlook 2014; IUCN: Gland, Switzerland, 2014. Available online: http://www.worldheritageoutlook.iucn.org/ (accessed on 15 June 2017).

3. Commonwealth of Australia. Reef 2050 Long-Term Sustainability Plan. Available online: https: / /www.environment.gov.au/system/files/resources/d98b3e53-146b-4b9c-a84a-2a22454b9a83/ files/reef-2050-long-term-sustainability-plan.pdf (accessed on 15 April 2017).

4. Great Barrier Reef Marine Park Authority (GBRMPA). Great Barrier Reef Climate Change Adaptation Strategy and Action Plan 2012-2017; GBRMPA: Townsville, Australia, 2012.

5. Payet, R.; Obura, D. The negative impacts of human activities in the East African region: An international waters perspective. Ambio 2004, 33, 24-33. [CrossRef] [PubMed]

6. Hall, M. Tourism and climate change: Knowledge gaps and issues. Tour. Recreat. Res. 2008, 33, 339-350. [CrossRef]

7. Wielgus, J.; Cooper, E.; Torres, R.; Burke, L. Coastal Capital: Economic Valuation of Coral Reefs in the Dominican Republic; Working Paper; World Resources Institute: Washington, DC, USA, 2010.

8. Great Barrier Reef Marine Park Authority (GBRMPA). Great Barrier Reef Tourism and Climate Change Action Strategy 2009-2012; GBRMPA: Townsville, Australia, 2009.

9. Alcock, D.J. Australia: Education and extension: Management's best strategy for the Great Barrier Reef Marine Park. In Planning Education to Care for the Earth; Palmer, J., Goldstein, W., Curnow, A., Eds.; IUCN: Gland, Switzerland, 1995; pp. 134-142.

10. De'ath, D.; Fabricius, A.E.; Sweatman, H.; Puotinen, M. The 27-year decline of coral cover on the Great Barrier Reef and its causes. Proc. Natl. Acad. Sci. USA 2012, 109, 17995-17999. [CrossRef] [PubMed]

11. Schott, C. Tourism and the Implication of Climate Change: Issues and Actions; Emerald Publishers: Bingley, UK, 2010.

12. Tiller, T.R.; Schott, C. The critical relationship between climate change awareness and action: An origin-based perspective. Asia Pac. J. Tour. Res. 2013, 18, 21-34. [CrossRef]

13. Becken, S.; Hay, J. Climate Change and Tourism: From Policy to Practice; Routledge: New York, NY, USA, 2012.

14. Scott, D. Why sustainable tourism must address climate change. J. Sustain. Tour. 2011, 19, 17-34. [CrossRef]

15. Gössling, S.; Scott, D.; Hall, C.M.; Ceron, J.P.; Dubois, G. Consumer behaviour and demand response of tourists to climate change. Ann. Tour. Res. 2012, 39, 36-58. [CrossRef]

16. Kroesen, M. Exploring people's viewpoints on air travel and climate change: Understanding inconsistencies. J. Sustain. Tour. 2013, 21, 271-290. [CrossRef]

17. Scott, D.; de Freitas, C.R.; Matzarakis, A. Adaptation in the tourism and recreation sector. In Biometeorology for Adaptation to Climate Variability and Change; Ebi, K.L., Burton, I., Hoeppe, P., Eds.; Springer: Dordrecht, The Netherlands, 2006; pp. 171-194.

18. Scott, D.; Jones, B.; Konopek, J. Exploring potential visitor response to climate-inducted environmental changes in Canada's Rocky Mountain National Parks. Tour. Rev. Int. 2008, 12, 43-56. [CrossRef]

19. Turton, S.; Hadwen, S.W.; Wilson, R. The Impacts of Climate Change on Australian Tourism Destinations: Developing Adaptation and Response Strategies-A Scoping Study; Cooperative Research Centre for Sustainable Tourism: Gold Coast, Australia, 2009.

20. Ramis, M.; Prideaux, B. The importance of visitor perceptions in estimating how climate change will affect future tourists flows on the Great Barrier Reef. In Tourism, Climate Change and Sustainability; Reddy, M., Wilkes, K., Eds.; Routledge: London, UK, 2013; pp. 173-188.

21. Hughes, T.P.; Day, J.C.; Brodie, J. Securing the future of the Great Barrier Reef. Nat. Clim. Chang. 2015, 5, 508-511. [CrossRef] 
22. Wynveen, C.J.; Kyle, G.T.; Sutton, S.G. Natural area visitors' place meaning and place attachment ascribed to a marine setting. J. Environ. Psychol. 2012, 32, 287-296. [CrossRef]

23. Buckley, R. Sustainable tourism: Research and reality. Ann. Tour. Res. 2012, 39, 528-546. [CrossRef]

24. Dawson, J.; Stewart, E.J.; Lemelin, H.; Scott, D. The carbon cost of polar bear viewing tourism in Churchill, Canada. J. Sustain. Tour. 2010, 18, 319-336. [CrossRef]

25. Higham, J.; Cohen, S. Canary in the coalmine: Norwegian attitudes towards climate change and extreme long-haul air travel to Aotearoa/New Zealand. Tour. Manag. 2011, 32, 98-105. [CrossRef]

26. Gössling, S.; Haglund, L.; Kallgren, H.; Revahl, M.; Hultman, J. Swedish air travellers and voluntary carbon offsets: Towards the co-creation of environmental value? Curr. Issues Tour. 2009, 12, 1-19. [CrossRef]

27. Hares, A.; Dickinson, J.; Wilkes, K. Climate change and the air travel decisions of UK tourists. J. Transp. Geogr. 2010, 18, 466-473. [CrossRef]

28. Becken, S. How tourists and tourism experts perceive climate change and carbon offset schemes. J. Sustain. Tour. 2004, 10, 114-130. [CrossRef]

29. Huebner, A. Public perceptions of destination vulnerability to climate change and implications for long-haul travel decisions to small island states. J. Sustain. Tour. 2012, 20, 939-951. [CrossRef]

30. Mair, J. Exploring air travellers' voluntary carbon-offsetting behaviour. J. Sustain. Tour. 2011, 19, $215-230$. [CrossRef]

31. Becken, $\mathrm{S}$. Tourists' perception of international air travel's impact on the global climate and potential climate change policies. J. Sustain. Tour. 2007, 15, 351-368. [CrossRef]

32. Dickinson, J.E.; Robbins, D.; Lumdsdon, L. Holiday travel discourses and climate change. J. Transp. Geog. 2010, 18, 482-489. [CrossRef]

33. Pidgeon, N. Public Understanding of Attitudes Towards Climate Change (Report 5: International Dimensions of Climate Change); UK Government Foresight Office: London, UK, 2011.

34. Bartle, I. A strategy for better climate change regulation: Towards a public interest orientated regulatory regime. Environ. Polit. 2009, 18, 689-706. [CrossRef]

35. Krippendorf, J. The Holiday Makers: Understanding the Impact of Leisure and Travel; Butterworth-Heinemann: Oxford, UK, 1987.

36. Goldberg, J.; Marshall, N.; Birtles, A.; Case, P.; Bohensky, E.; Curnock, M.; Gooch, M.; Parry-Husbands, H.; Pert, P.; Tobin, R.; et al. Climate change, the great barrier reef, and the response of Australians. Palgrave Commun. 2016, 1-8. [CrossRef]

37. Warren, K. Ecofeminist Philosophy: A Western Perspective on What It Is and Why It Matters; Rowman and Littlefield: Lanham, MD, USA, 2000.

38. Leopold, A. 'Wherefore Wildlife Ecology?' In Leopold 1991. In The River of the Mother of God, and Other Essays by Aldo Leopold; Flader, S.L., Callicott, J.B., Eds.; University of Wisconsin Press: Madison, WI, USA, 1991; pp. 336-337.

39. Norlock, K.J. Building receptivity: Leopold's Land Ethic and Critical Feminist Interpretation. J. Study Relig. Nat. Cult. 2011, 5, 491-509. [CrossRef]

40. Leopold, A. A Sand County Almanac, with Essays from Round River; Ballantine Books: New York, NY, USA, 1966.

41. Light, A. Urban Ecological Citizenship. In Democracy and the Claims of Nature; Minteer, B.A., Taylor, B.P., Eds.; Rowman and Littlefield Publishers: Lanham, MD, USA, 2002; pp. 153-173.

42. Taylor, B.P. Aldo Leopold's Civic Education. In Democracy and the Claims of Nature; Minteer, B.A., Taylor, B.P., Eds.; Rowman and Littlefield Publishers: Lanham, MD, USA, 2002; pp. 174-187.

43. Dewey, J. Democracy and Education; Simon and Schuster: New York, NY, USA, 1938.

44. Dewey, J. Art as Experience; Perigee: New York, NY, USA, 2005. (Originally Published in 1934)

45. Raber, J.B. Progressivism's Aesthetic Education: The Bildungsroman and the Struggle for the American School, 1890-1920. Ph.D. Thesis, Harvard University, Cambridge, MA, USA, 2014.

46. Dewey, J. Experience and Nature; Open Court Publishing/Waverly Press: Baltimore, MD, USA, 1925.

47. Prideaux, B.; Falco-Mammone, F. The Impacts of Cyclone Larry on Tourism in the Mission Beach, Tully and the Atherton Tablelands Region One Year Later; Centre for Tropical Tourism Research, James Cook University: Cairns, Australia, 2010. 
48. Turton, S.; Hadwen, W.; Wison, R. The Impacts of Climate Change on Australian Tourism Destinations: Developing Adaptation and Response Strategies-A Scoping Study; CRC for Sustainable Tourism Pty Ltd.: Gold Coast, Australia, 2007.

49. Intergovernmental Panel on Climate Change. Summary for Policy Makers. In Climate Change 2007: The Physical Science Basis; Contribution of Working Group 1 to the Fourth Assessment Report of the Intergovernmental Panel on Climate Change; Solomon, S., Qin, M., Manning, Z., Chen, M., Marquia, K., Averyt, M., Tignor, M., Miller, H., Eds.; Cambridge University Press: Cambridge, UK, 2007.

50. Berkelmans, R.; De'ath, G.; Kininmonth, S.; Skirving, W.J. A comparison of the 1998 and 2002 coral bleaching events of the Great Barrier Reef: Spatial correlation, patterns and predictions. Coral Reefs 2004, 23, 74-83. [CrossRef]

51. Bryant, N. Great Barrier Reef Fights to Retain UNESCO Status. Online BBC News Report. 1 February 2013. Available online: http:/ / www.bbc.co.uk/news/science-environment-21293736 (accessed on 7 June 2017).

52. Larwood, C. Climate Change Threatens Great Barrier Reef. Online BBC News Report. 22 October 2012. Available online: http://news.bbc.co.uk/2/hi/programmes/fast_track/9762256.stm (accessed on 7 June 2017).

53. Great Barrier Reef Marine Park Authority (GBRMPA). Science Information Needs for the Management of the Great Barrier Reef Marine Park 2009-2014. Available online: http:/ /www.gbrmpa.gov.au/_data/assets / pdf_file/0019/3376/GBRMPA_Scientific_Information_Needs.pdf (accessed on 28 April 2017).

54. Great Barrier Reef Marine Park Authority (GBRMPA). Great Barrier Reef Outlook Report 2014. Available online: http:/ /www.gbrmpa.gov.au/corp_site/about_us/great_barrier_reef_outlook_report (accessed on 28 April 2017).

55. Coghlan, A.; Kim, A.K. Interpretive layering in nature-based tourism: A simple approach for complex attractions. J. Ecotour. 2012, 11, 173-187. [CrossRef]

56. Zeppel, H. Climate change and tourism in the Great Barrier Reef Marine Park. Curr. Issues Tour. 2012, 15, 287-292. [CrossRef]

57. van Riper, C.J.; Kyle, G.T.; Sutton, S.G.; Yoon, J.I.; Tobin, R.C. Australian residents' attitudes toward pro-environmental behaviour and climate change impacts on the Great Barrier Reef. J. Environ. Plan. Manag. 2013, 56, 494-511. [CrossRef]

58. Slocum, R. Polar bears and energy-efficient lightbulbs: Strategies to bring climate change home. Environ. Plan. D 2004, 22, 413-438. [CrossRef]

59. Donnelly, D. Propensity for UK and German Travelers to Adapt Travel Intentions Due to Rising Awareness of Climate Change Issues; Report Prepared for Department of Resources, Energy and Tourism; Instinct and Reason consultants: Surrey Hill, Australia, 2008.

60. Tarrant, M.A.; Lyons, K.; Stoner, L.; Kyle, G.T.; Wearing, W.; Poudyal, N. Global citizenry, educational travel and sustainable tourism: Evidence from Australia and New Zealand. J. Sustain. Tour. 2014, 22, 403-420. [CrossRef]

61. Kemmelmeier, M.; Krol, G.; Kim, Y.H. Values, economics, and proenvironmental attitudes in 22 societies. Cross-Cult. Res. 2002, 36, 256-285. [CrossRef]

62. Jamal, T.; Watt, M. Climate change pedagogy and performative action: Toward community-based destination governance. J. Sustain. Tour. 2011, 19, 571-588. [CrossRef]

63. Orams, M. The effectiveness of environmental education: Can we turn tourists into 'greenies'? Prog. Tour. Hosp. Res. 1997, 3, 295-306. [CrossRef]

64. Satchabut, T. Effects of Recreation Participation and Tildenian Interpretation on Tourists' Environmental Concern. Ph.D. Thesis, Texas AandM University, College Station, TX, USA, 2013.

65. Zeppel, H. Education and conservation benefits of marine wildlife tours: Developing free-choice learning experiences. J. Environ. Educ. 2008, 39, 3-18. [CrossRef]

66. Zeppel, H.; Muloin, H. Conservation benefits of interpretation on marine wildlife tours. Hum. Dimens. Wildl. 2008, 13, 280-294. [CrossRef]

67. Bechtel, R.B.; Verdugo, V.C.; Asai, M.; Riesle, A.G. A cross-cultural study of environmental belief structures in USA, Japan, Mexico, and Peru. Int. J. Psychol. 2006, 41, 145-151. [CrossRef] 
68. Rauwald, K.S.; Moore, C.F. Environmental attitudes as predictors of policy support across three countries. Environ. Behav. 2002, 34, 709-739. [CrossRef]

69. Oreg, S.; Katz-Gerro, T. Predicting proenvironmental behavior cross-nationally: Values, the theory of planned behavior, and value-belief-norm theory. Environ. Behav. 2006, 38, 462-483. [CrossRef]

(C) 2017 by the authors. Licensee MDPI, Basel, Switzerland. This article is an open access article distributed under the terms and conditions of the Creative Commons Attribution (CC BY) license (http:/ / creativecommons.org/licenses/by/4.0/). 